\title{
In Vitro Culture of Mesenchymal Lineage Cells Established from the Colonial Tunicate Botryllus primigenus
}

\author{
Kazuo Kawamura*, Sae Takeoka, Show Takahashi and Takeshi Sunanaga \\ Laboratory of Cellular and Molecular Biotechnology, Faculty of Science, \\ Kochi University, Kochi 780-8520, Japan
}

\begin{abstract}
Body trunks were isolated from juvenile zooids of the Japanese colonial tunicate Botryllus primigenus and cultured in vitro to establish tissue-specific cell lines. Epidermal cells from some explants spread and formed a flat sheet consisting of vacuolated cells. They then dissociated into single cells, and their growth stopped within two weeks. Continuously proliferating cells were established from four explants. After the $20^{\text {th }}$ implantation, nuclear and mitochondrial DNAs were extracted from these cells. The nucleotide sequences of proliferating cell nuclear antigen (PCNA) and mitochondrial large ribosomal RNA (mtIrRNA) completely matched the PCNA and mtIrRNA taken from living colonies of $B$. primigenus; this shows that the four independently proliferating cells were indeed of the Botryllus origin. One cell line (Bp0306E10) comprised round-shaped cells with a diameter of 8-10 $\mu \mathrm{m}$. These cells have been cultured in vitro with a doubling time of approximately 24 hours since June, 2003 . The BrdU labeling index was approximately $2 \%$. Monoclonal antibodies raised against the cultured cells recognized a $28 \mathrm{kDa}$ polypeptide and stained free mesenchymal cells in vivo. G418-resistant subclonal cells could be established by introducing a tunicate retrotransposon loaded with the neomycin resistance gene into the cells by electroporation. This study is the first to succeed in producing a sustainable cell culture of Botryllus.
\end{abstract}

Key words: Botryllus, cell culture, G418, mesenchyme, PCNA, tunicate

\section{INTRODUCTION}

Botryllus and Botrylloides are well known budding tunicates that form flat colonies with many zooids scattered on a mesh-like common vascular system (Fig. 1A). Their specialized mode of life has attracted the attention of many scientists, for several reasons. A colony always contains three different generations of zooids, and each generation develops in a completely synchronized manner (Cima et al., 2003; Lauzon et al., 1992, 2002; Rinkevich et al., 1992). Furthermore, the lifespan of zooids is very short, i.e., a maximum of two weeks. Adult zooids undergo abrupt degeneration simultaneously accompanied by apoptotic cell death (Lauzon et al., 2000). They are phagocytized and absorbed by the colony. Finally, auto- and allorecognition occurs between neighboring colonies. When two colonies come in contact at their growing edges, the two independent vascular networks either fuse with, or reject, one another, a process similar to the graft-versus-host reaction in vertebrates (Oka and Watanabe, 1957a; Sabbadin, 1962; Mukai and Watanabe, 1974; Scofield et al., 1982; Scofield and Nagashima, 1983; Saito et al., 1994). This phenomenon is referred to as colony specificity (Oka and Watanabe, 1957a) and is interesting from the viewpoint of comparative immunology.

Botryllus primigenus is a Japanese endemic species. It

\footnotetext{
${ }^{*}$ Corresponding author. Phone: $+81-88-844-8313$;

Fax : +81-88-844-8313;

E-mail: address: kazuk@cc.kochi-u.ac.jp
}

doi:10.2108/zsj.23.245 is commonly found on rocky seashores along the southern coast of the Honshu and Shikoku Islands. This species is well known owing to the discovery of the genetic basis for its colony specificity. Oka and Watanabe (1957a) were the first to suggest that multiple alleles at a single locus govern auto- and allorecognition between different colonies in $B$. primigenus. Further, this species is well known because of presence of stem cells that play a significant role in both sexual and asexual reproductions. Oka and Watanabe (1957b) discovered a new type of budding called vascular budding in $B$. primigenus, wherein hemoblasts (a type of blood cell) aggregate to form new individuals (Fig. 1B). This indicates that hemoblasts act as multipotent somatic cells in the blood (Oka and Watanabe, 1957b, 1959). Germline cells are also derived from blood cells that are very similar to somatic hemoblasts (Mukai and Watanabe, 1976; Sunanaga et al., submitted). Until maturation, they pass through blastogenic generations. Similar observations were made in other species of Botryllus (Sabbadin and Zaniolo, 1979; Stoner and Weissman, 1996).

Botryllus primigenus has thus been a pivotal species in fields such as comparative immunology and stem cell biology. However, recent studies on this species have not necessarily utilized the technologies of cell and molecular biology in an efficient manner. This and forthcoming papers are aimed to renew $B$. primigenus as one of the model animals for modern molecular and cellular biology. In this paper, we tested $B$. primigenus cell culture and succeeded in establishing long-term proliferative cell lines. This is the first success in establishing a Botryllus cell culture and the second 

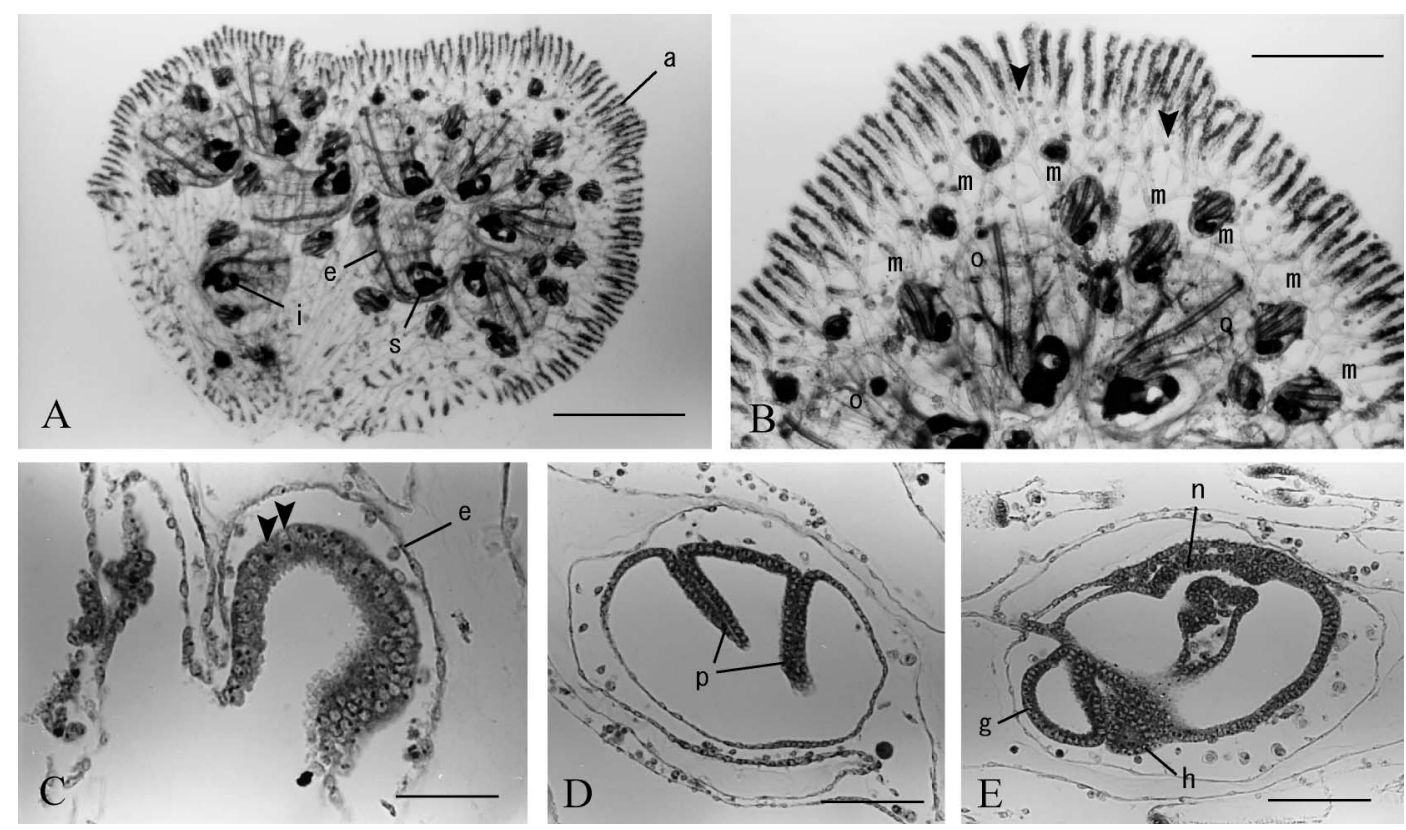

Fig. 1. A colony and stages of zooid development of Botryllus primigenus. (A) A colony, low magnification. Zooids and buds are surrounded by the vascular ampullae (a). e, endostyle; i, intestine; s, stomach. Bar, $2 \mathrm{~mm}$. (B) A colony, higher magnification. It contains three asexual generations, each of which is developmentally synchronized. The oldest (o) and middle $(\mathrm{m})$ generations are visible. Vascular buds are located at the colonial periphery (arrowheads). Bar, $1 \mathrm{~mm}$. (C-E) The youngest generation. (C) A bud of stage 3 . Arrowheads show mitotic figures. Bar, $25 \mu \mathrm{m}$. (D) A bud of stage 5. Pharyngeal folds (p) are developing. Bar, $50 \mu \mathrm{m}$. (E) A bud of stage 6. It forms the neural complex (n) on the dorsal side and the gut rudiment $(\mathrm{g})$ and the heart $(\mathrm{h})$ at the posterior end. Bar, $50 \mu \mathrm{m}$.

one in tunicates, following Polyandrocarpa misakiensis (Kawamura and Fujiwara, 1995). We consider the availability of Botryllus culture cells from viewpoints of cell biology, biochemistry, and molecular biology.

\section{MATERIALS AND METHODS}

\section{Animals}

Colonies of Botryllus primigenus were collected at Nabeta Bay, Izu Peninsula, Shizuoka Prefecture and at Uranouchi Inlet, Kochi Prefecture. They were attached to glass plates and reared in culture boxes settled near the Usa Marine Biological Institute, Kochi Univeristy.

\section{Tissue harvest}

Colonies on glass plates were rinsed briefly with $99 \%$ alcohol and heated for a few seconds for sterilization (Kawamura and Fujiwara, 1995). They were then incubated in millipore-filtered seawater (MS). Zooids were cut carefully with razor blades, and tissue fragments were picked up with forceps and transferred to cell culture medium in 96-well multiplates. The multiplates were incubated in a $\mathrm{CO}_{2}$ incubator in $4 \% \mathrm{CO}_{2}$ at $25^{\circ} \mathrm{C}$.

\section{Cell culture medium}

Modified MS (MMS) consisted of $90 \mathrm{ml} \mathrm{MS}$ and $30 \mathrm{ml}$ distilled water (cell culture grade) containing $10 \mathrm{mM}$ HEPES ( $\mathrm{N}$-(2-hydroxyethyl) piperazine-N'-2-ethanesulfonic acid). After autoclaving, antibiotics (100 U/ml penicillin and $100 \mu \mathrm{g} / \mathrm{ml}$ streptomycin) were added to the MMS. The growth medium for Botryllus contained five volumes of MMS, one volume of RPMI 1640 (Invitrogen), and 3\% fetal bovine serum (FBS, Wheaton). Medium was prepared immediately before use and was added to each well (dish) every three days.

\section{MTT assay}

After harvesting from the subconfluent culture, cells were resuspended in culture medium at a density of $5 \times 10^{5}$ cells $/ \mathrm{ml}$. The cell suspension $(0.5 \mathrm{ml}$ each) was dispensed in 24-well multiplates. The MTT (3-[4,5-dimethylthiazol-2-yl] -2,5-diphenyl tetrazolium bromide) assay for cell-number quantification was modified as described elsewhere (Kawamura et al., 1999). In brief, MTT (5 mg/ $\mathrm{ml}$ ) was dissolved in PBS. One tenth volume of MTT was added to the cell suspension and incubated for four hours at $25^{\circ} \mathrm{C}$. The reaction product (formazan) was dissolved overnight with the same volume of $10 \%$ SDS in $0.01 \mathrm{~N} \mathrm{HCl}$. It was monitored for absorbance at $600 \mathrm{~nm}$ and the reference wavelength of $690 \mathrm{~nm}$.

\section{BrdU incorporation}

Cells were plated on a chamber slide and cultured in growth medium for 24 hours. They were then incubated with $10 \mu \mathrm{M} 5$ bromo-2'-deoxyuridine (BrdU) for 15 minutes. The medium was replaced with new medium, and 30 minutes later cells were fixed

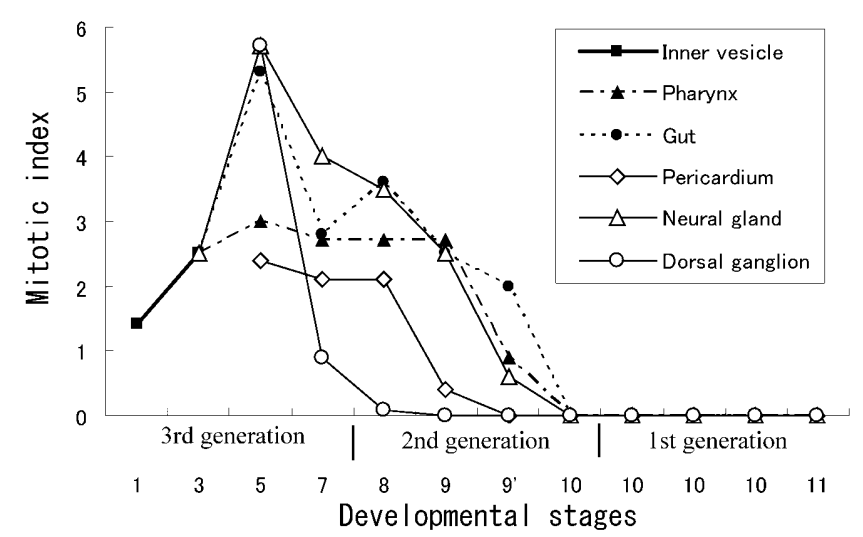

Fig. 2. Mitotic indices of differentiating tissues and organs in developing zooids of $B$. primigenus. For developmental stages of the oldest, middle and youngest $\left(1^{\text {st }}, 2^{\text {nd }}\right.$ and $\left.3^{\text {rd }}\right)$ generations, see Kawamura and Sugino (1999). 

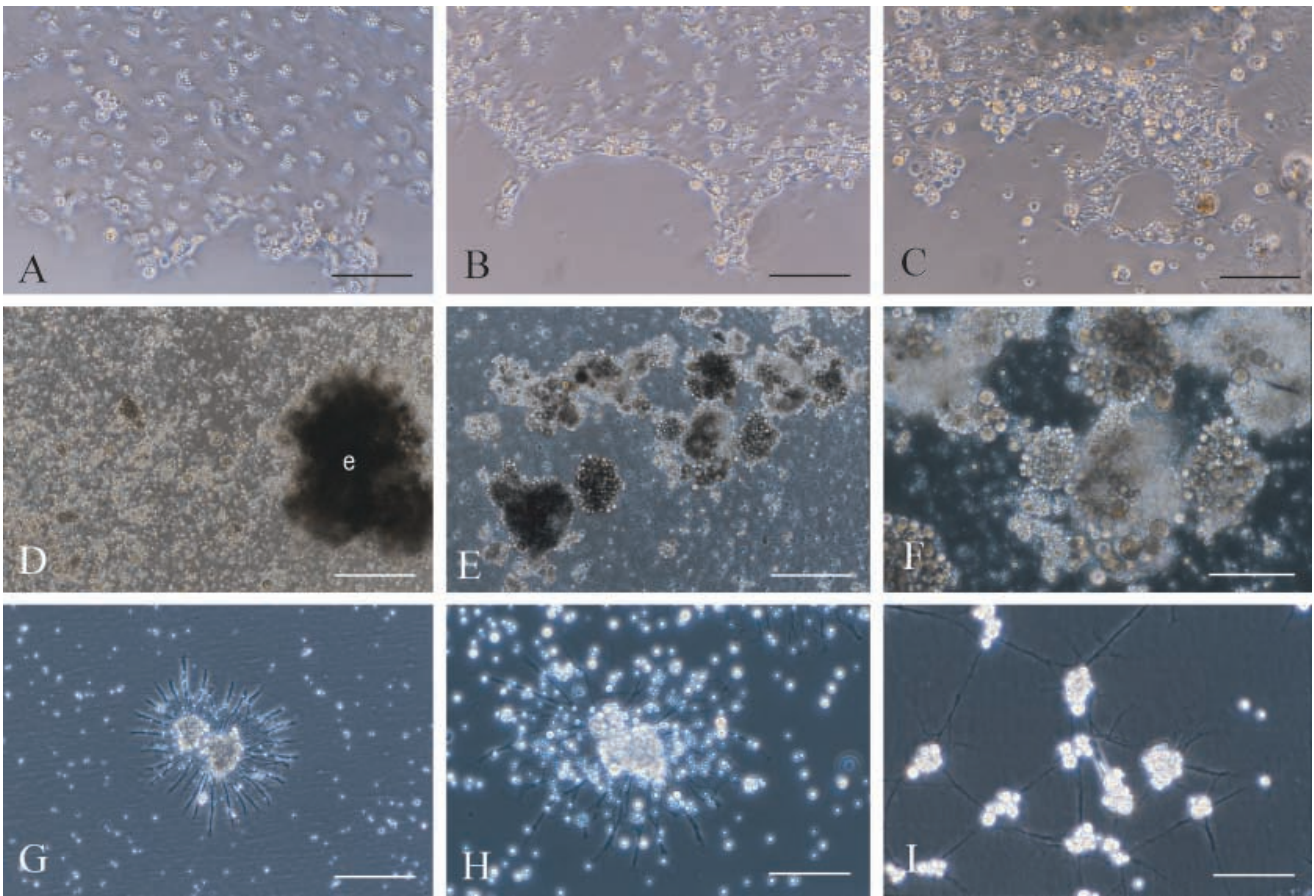

Fig. 3. In vitro proliferating cells in B. primigenus (1). (A-C) Epithelial sheets of vacuolated cells, perhaps epidermal in origin. (A) One week after tissue culture. Bar, $50 \mu \mathrm{m}$. (B) 1.5 weeks later. Bar, $50 \mu \mathrm{m}$. (C) Two weeks later. Bar, $50 \mu \mathrm{m}$. (D-F) Cell growth and morphology of cell line Bp0407B1. (D) Cells spreading from the explant (e), two days after tissue culture. Bar, $100 \mu \mathrm{m}$. (E) Proliferating cells and aggregates after five platings. Bar, $100 \mu \mathrm{m}$. (F) Higher magnification of (E). Note that the aggregates contain larger cells. Bar, $50 \mu \mathrm{m}$. (G-I) Cell growth and morphology of another cell line, Bp0310A6 after more than 10 platings. (G, H) Cell aggregates radiating fibrous matrices. Bars, $100 \mu \mathrm{m}$ and $50 \mu \mathrm{m}$, respectively. (I) Small cell aggregates interconnected by fibrous matrices. Bar, $25 \mu \mathrm{m}$.
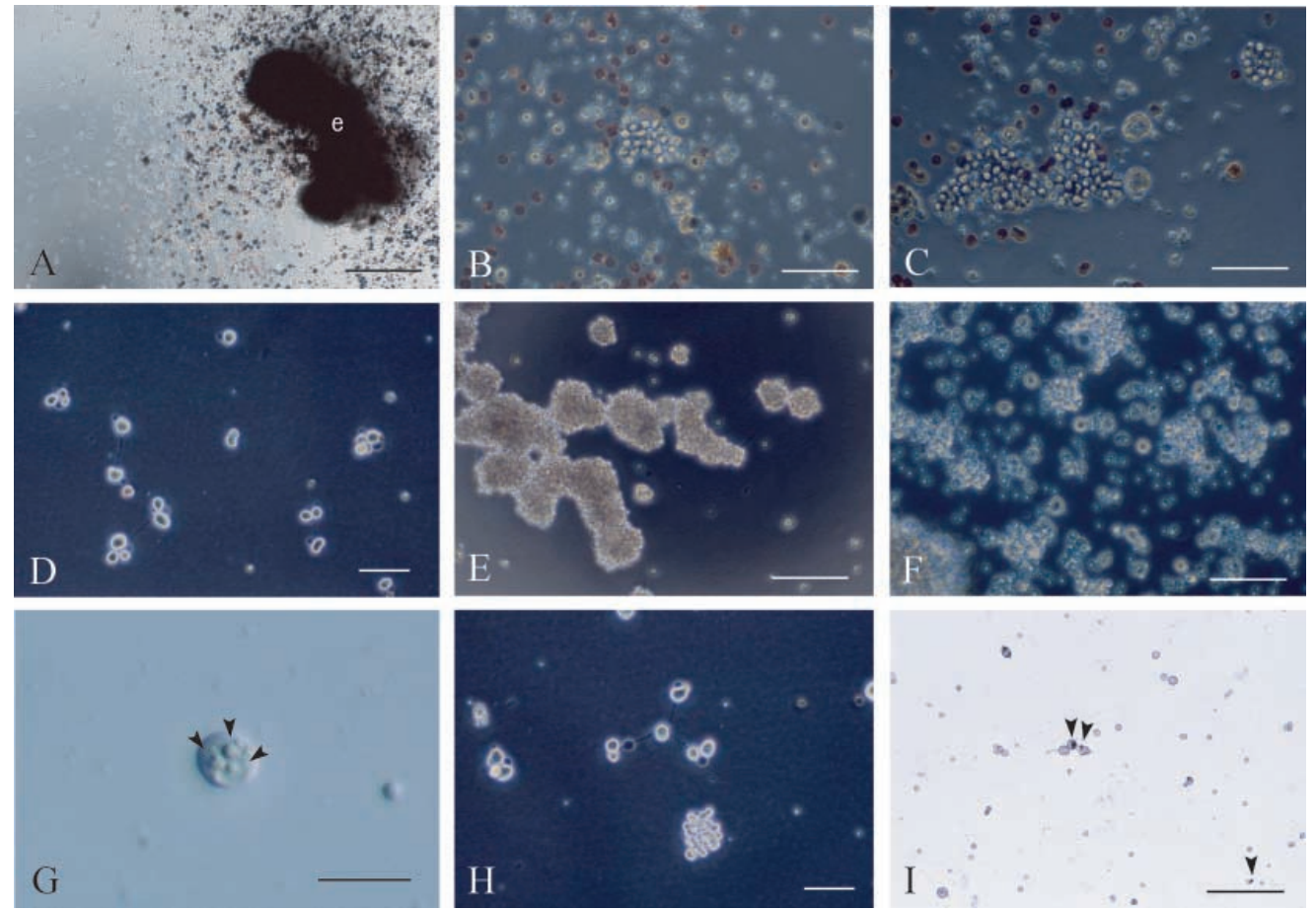

Fig. 4. In vitro proliferating cells in B. primigenus (2). Cell line Bp0306E10 and its subclones are shown. (A-C) Primary cell culture. (A) Cells spreading from the explant (e), two days after tissue culture. Bar, $100 \mu \mathrm{m}$. (B, C) Proliferating cells 10 and 15 days after implantation, respectively. Bars, $50 \mu \mathrm{m}$. (D-F) Subcultures of proliferating cells. (D) Adherent cells, round or somewhat amorphous in shape. Bar, $25 \mu \mathrm{m}$. (E) Cell aggregates detached from the substratum. Bar, $50 \mu \mathrm{m}$. (F) Heterogeneous cell population appearing after long-term culture without plating. Bar, $50 \mu \mathrm{m}$. (G) A large cell with several vacuoles (arrowheads) in the cytoplasm after long-term culture. Bar, $20 \mu \mathrm{m}$. (H) Cell morphology of subclone Bp0306E10D1. Bar, $25 \mu \mathrm{m}$. (I) BrdU-incorporating cells in culture (arrowheads). Bar, $50 \mu \mathrm{m}$. 
with $70 \%$ ethanol in $50 \mathrm{mM}$ glycine buffer ( $\mathrm{pH} 2.0)$. Labeled cells were stained with anti-BrdU antibody followed by anti-mouse IgG$A P$, using a BrdU detection kit (Boehringer).

\section{Genomic DNA}

Cultured cells $\left(\sim 10^{8}\right)$ were harvested in a conical tube and washed twice with cold PBS. They were solubilized with $0.5 \%$ SDS and $0.01 \%$ proteinase $\mathrm{K}$ in $10 \mathrm{mM} \mathrm{Tris} / \mathrm{HCl}(\mathrm{pH} 8.0)$ and $100 \mathrm{mM}$ EDTA for 20 hours at $50^{\circ} \mathrm{C}$. Colonies of $B$. primigenus were frozen and crushed in liquid $N_{2}$. The resultant powder was solubilized in the same manner as cultured cells. The extracts were further denatured in $80 \%$ formamide. Genomic DNA was stored in the refrigerator until use. For the construction of a genomic library, DNA was cut by the restriction enzyme Sau3A. Both ends of DNA fragments were filled with $A$ and $G$. These partial fill-in products were ligated to $\lambda$ Fix II vector (Stratagene), then packaged using a $\lambda$ Packaging Kit (Amersham Pharmacia Biotech.).

\section{PCR amplification and DNA sequencing}

The polymerase chain reaction (PCR, Saiki et al., 1988) was performed with genomic DNA as the template and primers we designed from cDNA nucleotide sequences: BpPCNA1 (5'GGATATGCTAGAACTTCAGTTTGA), BpPCNA2 (5'-GTTAATATGCGCTGTCATTATGTG), BPYC1 (5'-TGAGTGATACCTATAGTTGGTG), and BpYC2 (5'-ATAAGTCGACATCGAGGTCGTAAA). Ex Taq DNA polymerase (Takara Bio Inc.) was used under the following reaction conditions: $94^{\circ} \mathrm{C}$ for $0.5 \mathrm{~min}$ (one cycle); $94^{\circ} \mathrm{C}$ for 0.5 $\min , 53^{\circ} \mathrm{C}$ for $1 \mathrm{~min}, 72^{\circ} \mathrm{C}$ for $1.5 \mathrm{~min}$ (30 cycles); $72^{\circ} \mathrm{C}$ for $4 \mathrm{~min}$ (one cycle).

For cycle sequencing, a BigDye Terminator (v3.1) Cycle Sequencing Kit (Applied Biosystems) was used. Reaction products were analyzed with an ABI Prism 3100 DNA sequencer (Applied Biosystems).

\section{Preparation of monoclonal antibody}

Confluent cells of Botryllus cell line Bp0306E10A6 were harvested from two 24-well multiplates, washed once with PBS, resuspended in $1 \mathrm{ml}$ PBS, and frozen until use. BALB/c 3T3 mice were immunized five times with $0.2 \mathrm{ml}$ of cell suspension conjugated with the same volume of Freund's adjuvant. Spleen cells were fused with NS1/AG4 myeloma cells and screened by HAT medium. Positive hybridomas were cloned, and the culture media were stored in a refrigerator in the presence of $0.05 \% \mathrm{NaN}_{3}$.

\section{SDS-PAGE and western blotting}

Colonies of $B$. primigenus ( $1.5 \mathrm{~g}$, wet weight) were powdered in liquid $\mathrm{N}_{2}$. The powder was mixed with $2 \mathrm{ml}$ of $10 \mathrm{mM}$ TrisCl $(\mathrm{pH}$ 8.0) and homogenized in a glass homogenizer on ice. After centrifugation at $15 \mathrm{~K} \mathrm{rpm}$ for 5 minutes, the supernatant was separated from the pellet, and aliquots were mixed with an equal volume of SDS sample buffer. The pellet was dissolved directly in SDS sample buffer. Electrophoresis was done on a $15 \%$ polyacrylamide gel containing $0.1 \%$ SDS in $0.375 \mathrm{M}$ Tris- $\mathrm{HCl}$ ( $\mathrm{pH} 8.8$ ) (Laemmli, 1970). Polypeptide bands were electrically blotted onto nitrocellulose (NC) membrane (Biorad) at $300 \mathrm{~mA}$ for 1.5 hours in Tris-glycine buffer (25 mM Tris, $195 \mathrm{mM}$ glycine, 20\% methanol). The NC membrane was blocked with $2 \%$ skim milk and stained with the primary antibody for $30 \mathrm{~min}$ at room temperature. It was washed twice with PBST (PBS $+0.1 \%$ Tween 20), stained with the anti-mouse secondary antibody labeled with HRP (Vector), and colored by diaminobenzidine.

\section{Immunohistochemistry}

The cell suspension was left for 30 minutes on cover slips coated with poly-L-lysine. Cells were fixed in $2 \%$ paraformaldehyde at $4^{\circ} \mathrm{C}$ for 30 minutes and washed with PBS. Subsequent procedures were the same as those for the NC membrane. Colonies of
B. primigenus were fixed in $2 \%$ paraformaldehyde at $4^{\circ} \mathrm{C}$ for 60 minutes. After washing with PBS, they were dehydrated with ethanol, embedded in Technovit 8100 (Kulzer, Wehrheim), serially sectioned, and mounted on cover slips. The subsequent procedure of immunostaining was the same as that for the NC membrane, except that the secondary antibody was labeled with Texas Red (Vector) instead of HRP.

\section{Electroporation}

Cells (about $5 \times 10^{6}$ ) mixed with $20 \mu \mathrm{g}$ of plasmid were preincubated for 10 minutes in $400 \mu \mathrm{l}$ saline $\mathrm{G}$, then transferred to a sterilized cuvette with a $0.4 \mathrm{~cm}$ gap. Electroporation was carried out with a Gene Pulser Xcell (Bio-Rad) at $200 \mathrm{~V}$ and $100 \mu \mathrm{F}$.

\section{RESULTS}

\section{Mitotic activity of cells and tissues}

Similarly to other botryllid tunicates, a colony of $B$. primigenus consists of three generations of asexual individuals (Fig. 1B; Kawamura and Sugino, 1999). The youngest generation begins with a disc-like bud primordium, forms a bud vesicle (stage 3), and commences organogenesis (stage 5; Fig. 1C, D, E). The middle generation undergoes morphogenesis most actively, and the oldest generation attains functional maturity. Each generation lasts for 4-5 days; hence, the maximum lifespan of a single zooid is two weeks. Figure 2 shows the mitotic indices (MI) of developing zooids. A double-walled bud vesicle (stage 3 ) showed an Ml of 1.52.5 in the inner multipotent epithelium (arrowheads, Fig. 1C). At stage 5, the $\mathrm{Ml}$ reached a maximum (approximately 5.5 ) in the gut rudiment and neural complex (precursor of the neural gland and ganglion; Fig. 1D, E). Thereafter, the $\mathrm{Ml}$ of the ganglion cells decreased rapidly to nearly zero; however, the Ml of the neural gland, pharynx, and gut remained stable until the mid-phase of the middle generation. Finally, the $\mathrm{Ml}$ of all tissues and organs reached zero by the end of this generation. Based on these observations, we chose the middle generation for the Botryllus cell culture.

\section{Establishment of cell lines}

Body trunks were isolated from the middle generation of colonies and consecutively implanted in each well of a 96-

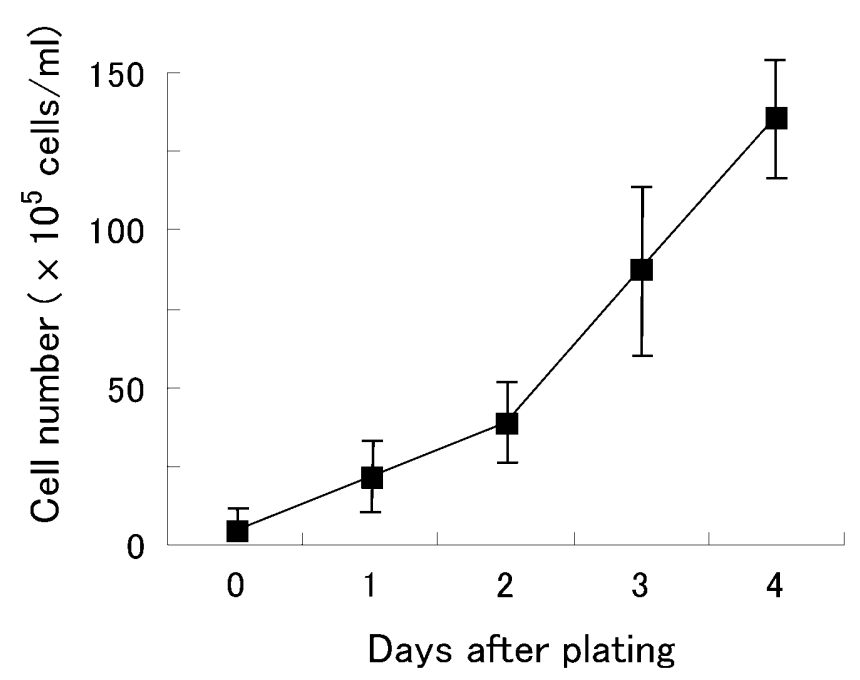

Fig. 5. Cell growth curve of subclonal cell line Bp0306E10D1. The cell number was estimated by MTT assay. Means \pm SD. 
well multiplate. Approximately one week later, vacuolated epithelial cells, which may be epidermal in origin, spread on the substratum to form a flat sheet in a few wells (Fig. 3A). They continued to grow for a week, then dissociated into

A

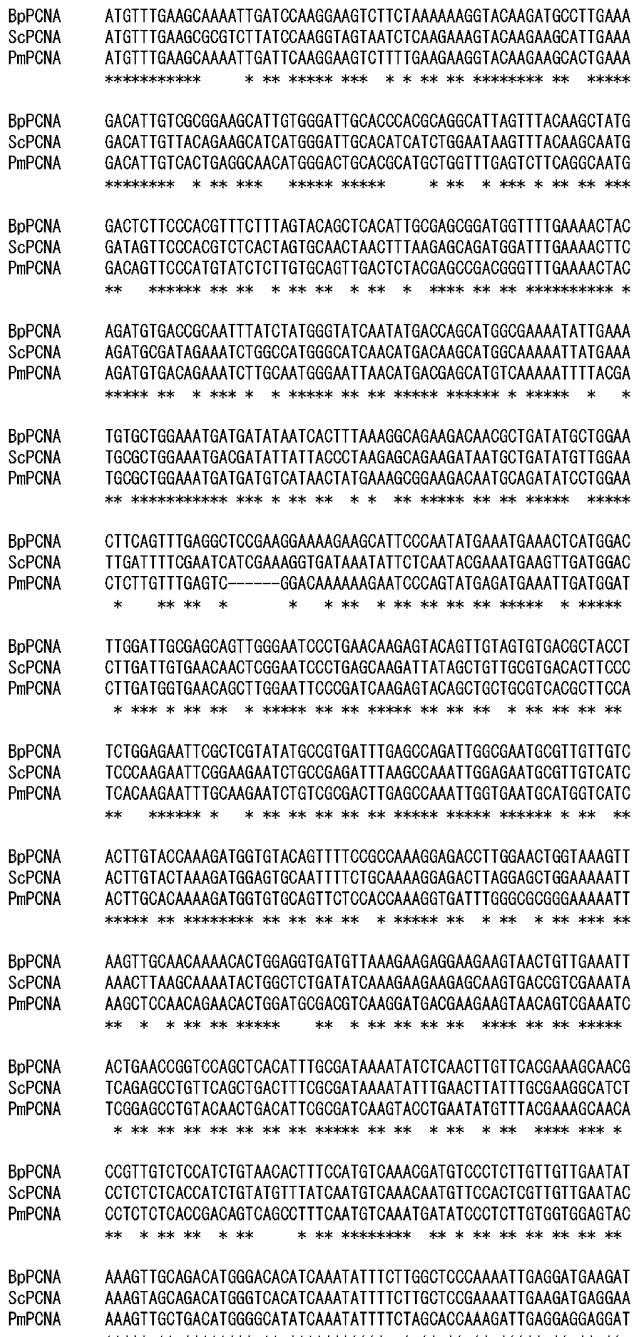

single cells and finally disappeared (Fig. 3B, C). In several wells, continuously proliferating cells of four types appeared. One type (Bp0407B1) spread away from the explant at first (Fig. 3D) and later grew as loose aggregates in which larger
B

\begin{tabular}{|c|c|}
\hline $\begin{array}{l}\text { Colony } \\
\text { Culture }\end{array}$ & $\begin{array}{l}\text { GATATGCTAGAACTTCAGTTTGAGGCACCGAAGGAAAAGAAGCATTCCCAATATGAAATG } \\
\text { GATATGCTAGAACTTCAGTTTGAGGCACGGAAGGAAAGAAGCATTCCCAATATGAAAT } \\
* * * * * * * * * * * * * * * * * * * * * * * * * * * * * * * * * * * * * * * * * * * * * * * * * * * * * * *\end{array}$ \\
\hline Colony & AAACTCATGGACTIGGATTGGGAGGAGTTGGGAATCCCTGAAGAAGAGTACAGCTGTAGT \\
\hline Culture & $\begin{array}{l}\text { AAACTCATGGACTTGGTTGGGAGAGTTGGGATCCCTGAACAAGAGTACAGCTGTAGT } \\
* * * * * * * * * * * * * * * * * * * * * * * * * * * * * * * * * * * * * * * * * * * * * * * * * * * * * * * *\end{array}$ \\
\hline $\begin{array}{l}\text { Colony } \\
\text { Culture }\end{array}$ & $\begin{array}{l}\text { GTGACCCTACCTTCTGGAGATTCGCTCGTATATGCCGTGATTIGAGCCAGATTGGGGAA } \\
\text { GTGACCTACCTTCTGGAGAATTGGTGGTATATGCGGGGATTGAGCCAGATTGGGGA } \\
* * * * * * * * * * * * * * * * * * * * * * * * * * * * * * * * * * * * * * * * * * * * * * * * * * * * * * * *\end{array}$ \\
\hline $\begin{array}{l}\text { Colony } \\
\text { Culture }\end{array}$ & 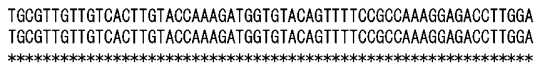 \\
\hline $\begin{array}{l}\text { Colony } \\
\text { Culture }\end{array}$ & $\begin{array}{l}\text { ACTGGTAAAGTTGAGTTGCACAAAACACTGGAGGTGATGTTAAAGAAGAGGAAGAGGA } \\
\text { ACTGGTAAAGTTGAGTGGAACAAAACACTGGAGGTGATGTTAAAGAAGAGGAGAAGTA } \\
* * * * * * * * * * * * * * * * * * * * * * * * * * * * * * * * * * * * * * * * * * * * * * * * * * * * * *\end{array}$ \\
\hline $\begin{array}{l}\text { Colony } \\
\text { Culture }\end{array}$ & $\begin{array}{l}\text { ACTGTTGAAATTACTGAACCGGTCCAGCTCACATTTGCGATAAAATATCTCAACTTGTTC } \\
\text { ACTGTTGAAATTACTGAACCGGTCCAGCTCACATTTGCGATAAAATATCTCAACTTGTC } \\
* * * * * * * * * * * * * * * * * * * * * * * * * * * * * * * * * * * * * * * * * * * * * * * * * * * * * *\end{array}$ \\
\hline $\begin{array}{l}\text { Colony } \\
\text { Culture }\end{array}$ & $\begin{array}{l}\text { ACGAAAGCAACGCCGTTGICTCCATCTGTAACGCTITCCATGTCTAACGATGTCCCTCIT } \\
\text { ACGAAAGCAACGCCGTTGTCTCCATCTGTAACGCTTTCCATGTCTAACGATGTCCCTCTT } \\
* * * * * * * * * * * * * * * * * * * * * * * * * * * * * * * * * * * * * * * * * * * * * * * * * * *\end{array}$ \\
\hline $\begin{array}{l}\text { Colony } \\
\text { Culture }\end{array}$ & $\begin{array}{l}\text { GTTGTTGAATATAAAGTTGCAGACATGGGACACATCAATATTICTTGGCTCCCAAAATT } \\
\text { GTTGTGAATATAAGTTGGAGACATGGACACATCAATATTCTGGCCCCAAATT } \\
* * * * * * * * * * * * * * * * * * * * * * * * * * * * * * * * * * * * * * * * * * * * * * * * * * * * * * *\end{array}$ \\
\hline $\begin{array}{l}\text { Colony } \\
\text { Culture }\end{array}$ & $\begin{array}{l}\text { GAGGATGAAGATGCCGAAGAGTAAATTATTCTGTGTATTACTGTCGCGTATAATTG } \\
\text { GAGGATGAAGATGCCGAAGAGTAAATTATTCTGTGTATTACTGTCGCGTATAATTG }\end{array}$ \\
\hline
\end{tabular}

Fig. 6. Multiple alignment of genes encoding PCNA. (A) Comparison of the ORF from B. primigenus with those from related species, $S$. clava and $P$. misakiensis. The ORFs were $75 \%$ identical to one another. (B) Comparison of a gene fragment taken from colonies with that from culture cells. The sequences were $100 \%$ identical to each other.
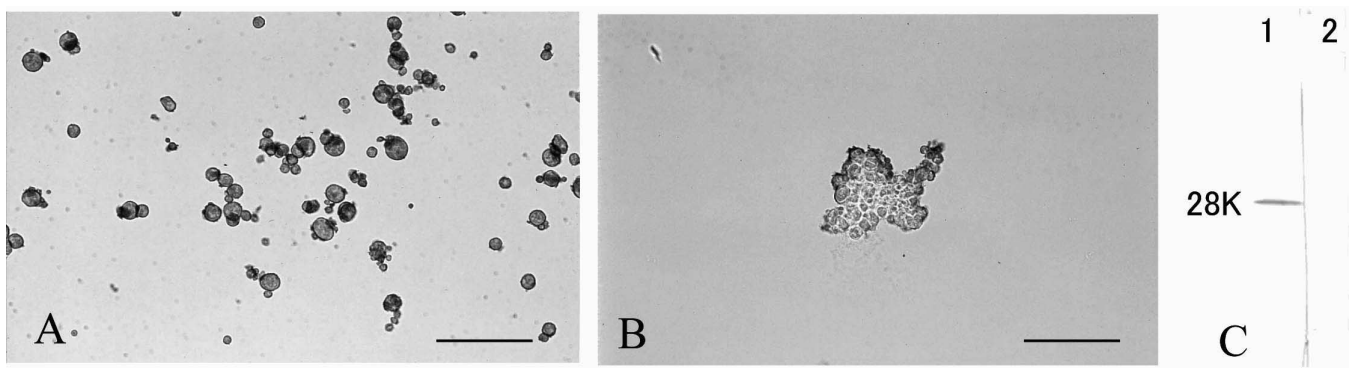

Fig. 7. Immunostaining of culture cells and proteins using the monoclonal antibody raised against cultured Bp0306E10 cells. (A) Dissociated single cells were stained with the antibody. Bar, $50 \mu \mathrm{m}$. (B) Aggregated cells were not stained, except at the periphery of the aggregate. Bar, $50 \mu \mathrm{m}$. (C) Western blot of crude extracts from Botryllus colonies. Lane 1, Water-insoluble fraction of the extracts. Lane 2, Water-soluble fraction of the extracts. 
cells appeared (Fig. 3E, F). The second and third types (Bp0310A6 and Bp0310C10, respectively) formed aggregates of various cell sizes. The aggregates extended matrix substances in a radial manner when they were distant from each other (Fig. 3G, H). If small aggregates were located near one another, they were interconnected (Fig. 3I). The fourth type of cell (Bp0306E10) appeared as cell aggregates (Fig. 4A, B, C). These cells were round or somewhat amor- phous in shape, with a diameter of 8-10 $\mu \mathrm{m}$, and had no apparent vacuoles in their cytoplasm (Fig. 4D). They adhered firmly to the substratum, and when the cells became subconfluent, they formed large cell masses that were often detached from the substratum (Fig. 4E). Cumulative cultures gave rise to a smaller and a larger type of cell (5-6 $\mu \mathrm{m}$ and 12-15 $\mu \mathrm{m}$ in diameter, respectively; Fig. 4F). Unlike the smaller cells, the larger cells contained several
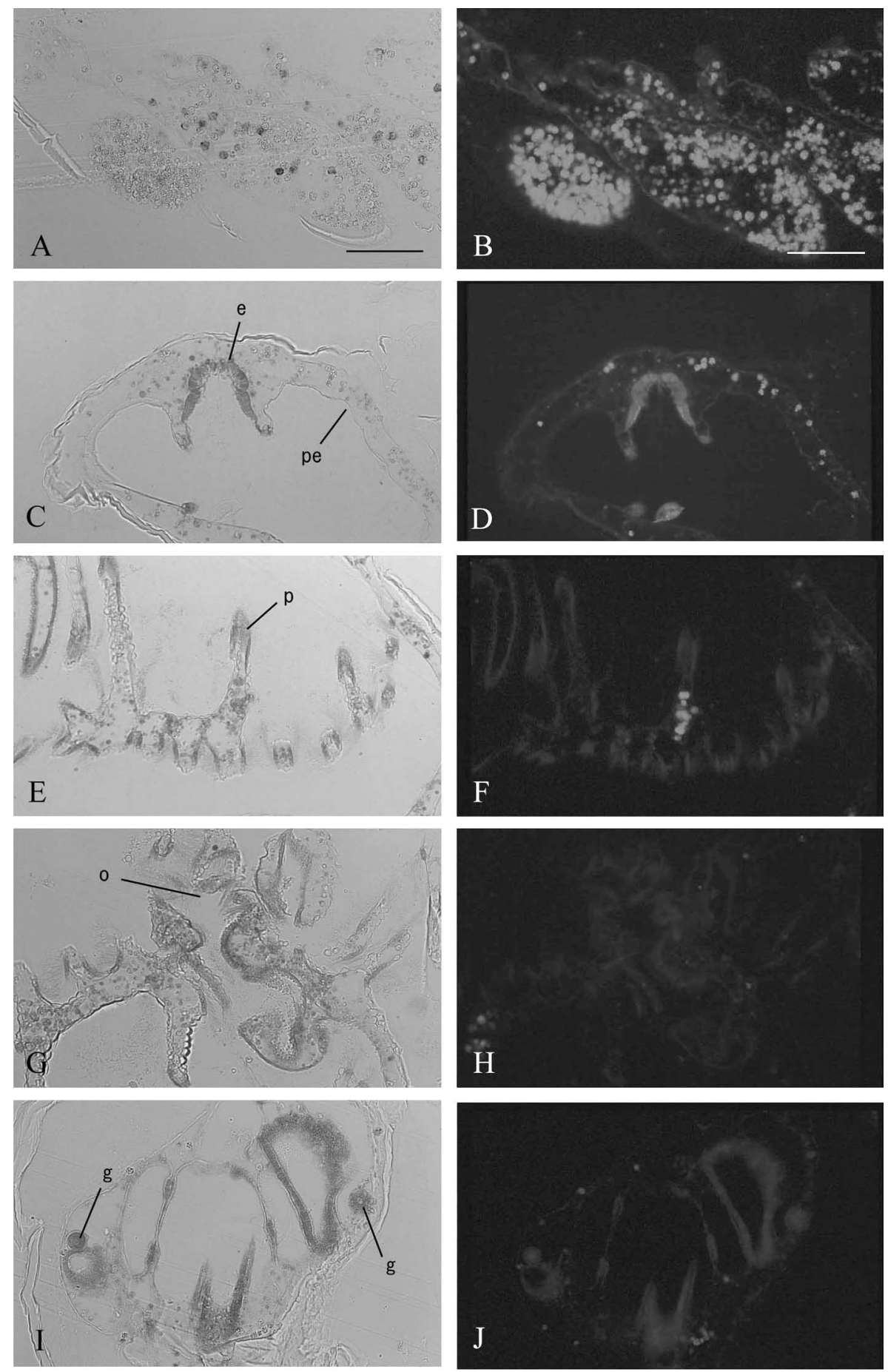

Fig. 8. Immunohistochemistry using anti-P28 monoclonal antibody. (A, C, E, G, I) Bright field microscopy. Bar, $50 \mu \mathrm{m}$. (B, D, F, H, J) Fluorescence microscopy. Bar, $50 \mu \mathrm{m}$. (A, B) Coelomic cells in the vascular ampullae. (C, D) Body trunk. e, endostyle; pe, peribranchial epithelium. (E, F) Pharynx (p). (G, H) Oesophagus (o). (I, J) A developing zooid with gonads (g). 
vacuoles in the cytoplasm (Fig. 4G). After cloning, mediumsized cells were obtained without any apparent vacuoles in the cytoplasm (Fig. $4 \mathrm{H}$ ).

Clonal cells (Bp0306E10D1) proliferated with a doubling time of approximately 24 hours (Fig. 5). Immediately after plating, the cells grew slowly. However, after 2 days of culturing, the growth curve became steep; this suggested that the conditioned culture medium might facilitate cell growth. DNA synthesis was assessed by immunocytochemistry of BrdU-incorporating cells. Positive cells had a variable size ranging from 5 to $10 \mu \mathrm{m}$ in diameter (Fig. 4l). The labeling index was $2.1 \% \pm 0.8 \%$, which suggested that the $S$ phase had lasted for approximately $30 \mathrm{~min}$.

\section{Comparison of genomic sequences}

Genomic DNA was extracted from colonies of B. primigenus, and the gene for proliferating cell nuclear antigen (BpPCNA) was cloned and sequenced (Accession Number, AB239703). This sequence was $75 \%$ identical with homologous gene sequences from Styela clava and $P$. misakiensis (Accession number, AB239704). Four types of cell lines (Bp0407B1, Bp0310A6, Bp0310C10, and Bp0306E10) and a subclone of Bp0306E10 (Bp0306E10D1) were harvested at the $20^{\text {th }}$ subculture (6 months later). Nuclear DNA was extracted from these cells, and the gene for PCNA was cloned and sequenced. As the sequences were identical with one another, only that of Bp0306E10D1 was used for alignment (Fig. 6). The result showed that the sequence from cultured cells was completely consistent with that from living colonies. An identical sequence was obtained from the cells of the $50^{\text {th }}$ subcultures (one year later). A gene encoding the mitochondrial large ribosomal RNA was cloned from all four cell lines and compared with that from colonies of $B$. primigenus. Except for base substitutions at several sites, the sequences were identical with one another (data not shown).

\section{Preparation of monoclonal antibody recognizing Botryl- Ius cell lines}

A monoclonal antibody (3E9A5) was raised against the cell line Bp0306E10. The antibody stained dissociated cells in the culture (Fig. 7A), but not the cytoplasm of aggregated cells, except at the periphery of the aggregate (Fig. 7B). On performing SDS-PAGE and western blotting of the Botryllus homogenates, we found that the antibody recognized a single band of $28 \mathrm{kDa}$. This band appeared in the water-insoluble fraction of the homogenate (Fig. 7C).

In the colonies, the anti-P28 antibody heavily stained mesenchymal cells in the vascular ampullae (Fig. 8A, B). It weakly stained the endostyle (Fig. $8 \mathrm{C}, \mathrm{D}$ ), but did not recognize the epidermis, peribranchial epithelium, pharynx (Fig. $8 \mathrm{E}, \mathrm{F}$ ), oesophagus (Fig. 8G, H), stomach, intestines, and gonads (Fig. 8I, J).

\section{Establishment of neomycin-resistant subclonal cell lines}

A Polyandrocarpa retrotransposon loaded with the neomycin resistance gene was prepared (Kawamura et al., unpublished data). The construct was introduced into clonal Bp0306E10D1 cells by electroporation. Such cells not only survived but also proliferated in the presence of $0.2 \mathrm{mg} / \mathrm{mL}$ G418 for at least 10 months (Fig. 9B, C). In the negative
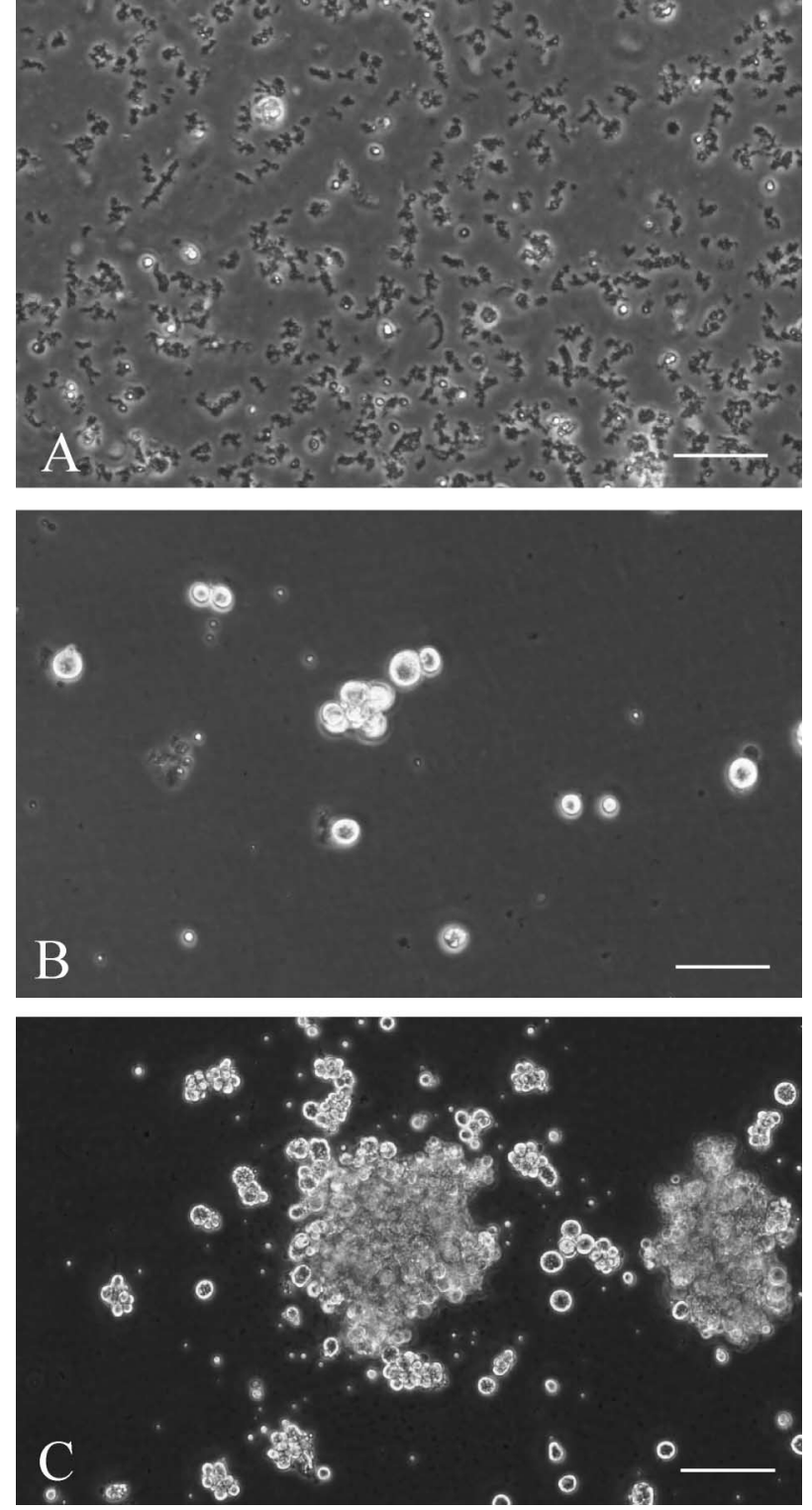

Fig. 9. Cell growth of a G418-resistant cell line. Retrotransposon loaded with the neomycin resistance gene was introduced into Bp0306E10D1, after which the cells (Bp0306E10D1neo) were treated with $200 \mu \mathrm{g} / \mathrm{ml} \mathrm{G} 418$. (A) A control without electroporation, one week later. All cells were dead. Bar, $25 \mu \mathrm{m}$. (B) Bp0306E10D1neo, one week later. Bar, $25 \mu \mathrm{m}$. (C) Bp0306E10D1neo, three weeks later. Bar, $25 \mu \mathrm{m}$.

control without electroporation, cells died within about a week in the presence of G418 (Fig. 9A). These results indicated that neomycin-resistant subclonal cell lines had been established successfully.

\section{DISCUSSION}

Differences in cell culture method from previous studies In tunicates, blood cells were used for early attempts at cell culture because they can be collected and handled with ease. Blood cells from some adult tunicates continue to exhibit proliferative potential in vivo and in vitro. In S. clava, for example, the hematopoietic nodule incorporates $\left[{ }^{3} \mathrm{H}\right]$ thymidine in vivo (Ermak, 1977), and allogeneic stimuli and 
cytokines induce blood cell proliferation in vivo and in vitro (Raftos and Cooper, 1991; Raftos et al., 1991). In Botrylloides diegense, a large number of free blood cells are labeled with $\left[{ }^{3} \mathrm{H}\right]$ thymidine (Ermak, 1981). In Ciona intestinalis, lymphocyte-like cells show cytotoxic activity (Peddie and Smith, 1993) and are capable of mitogen-induced cell proliferation in vitro (Peddie et al., 1995). Despite these findings, attempts to culture blood cells in vitro ended in failure for a long time.

Budding tunicates are known to have proliferative epithelial cells other than blood cells. The peribranchial (atrial) epithelium is a multipotent tissue in Symplegma reptans (Kawamura and Nakauchi, 1986a), B. schlosseri (Berrill, 1941; Izzard, 1973), B. primigenus (this study), and $P$. misakiensis (Kawamura and Nakauchi, 1986b). In fact, proliferative cell lines were established successfully for the first time from the peribranchial epithelium of $P$. misakiensis (Kawamura and Fujiwara, 1995). In the present study, we did not try to isolate the peribranchial epithelium from $B$. primigenus because it was too small to manipulate. Instead, to establish Botryllus cell lines, we used body trunks of the middle generation that contained a developing pharynx, gut, and neural complex.

In previous studies, the cell culture media contained seawater or a salt solution of the same osmolarity as seawater (Warr et al., 1977; Rinkevich and Rabinowitz, 1993). They were mixed with nutrients such as DMEM (Rinkevich and Rabinowitz, 1993) and RPMI 1640 (Raftos et al., 1990; Peddie et al., 1995). The pioneering success obtained with the Polyandrocarpa cell culture was primarily due to the low osmotic pressure (830 $\left.\mathrm{mO}_{\mathrm{sm}}\right)$ and low $\mathrm{pH}(6.8)$ of the culture medium (Kawamura and Fujiwara, 1995). Although this medium could also be used for the Botryllus cell culture, many cells underwent morphological changes and cell growth retardation in a long-term culture (data not shown). In the present study, the osmotic pressure of the basal medium was further lowered to approximately $600 \mathrm{mOSM}$. Instead of DMEM, RPMI 1640 was used as the nutrient source. This new culture medium required $4 \% \mathrm{CO}_{2}$ as a supplement. These revised methods effectively supported the morphology and proliferative activity of Botryllus cells for more than two years. This medium was also effective in the cell culture of $C$. intestinalis; however, it was not very effective in culturing Polyandrocarpa cell lines (data not shown).

\section{Proliferative cells in the body trunk of $B$. primigenus}

In this study, we chose the middle generation as the source of tissue explants, because in $B$. primigenus the neural complex, pharynx, and gut maintained high mitotic activities (the MI was approximately 2.5) until the mid-stage of the middle generation. In $B$. schlosseri, the cells of the neural complex divide and differentiate into nerve cells in the middle generation (Burighel et al., 1998). Similarly, in $P$. misakiensis, the dorsal strand (posterior extension of the neural complex) consists of undifferentiated cuboidal cells that differentiate into nerve cells (Koyama, 2002). In $B$. diegense, cell proliferation in the gut occurs only during bud development (Ermak, 1981). In B. primigenus, the gut rudiment showed the highest mitotic activity $(\mathrm{Ml}=5.5)$ at stage 5 of the youngest generation. Thereafter, it maintained a moderate mitotic activity during the middle generation, branching into three lobes that differentiate into the stomach, pyloric caecum, and intestine (cf. Berrill, 1941; Burighel, 1970; Izzard, 1973; Burighel et al., 1977, 1984, 1998; Casagrande et al., 1993; for review see Kawamura and Sugino, 1999). In the pharynx consisting of outer and inner branchial epithelia (cf. Casagrande et al., 1993), mitotic figures were observable until the stigmata were perforated.

Developmental synchrony is one of the most fascinating features of Botryllus and Botrylloides (Cima et al., 2003; Lauzon et al., 1992, 2002; Rinkevich et al., 1992). At the end of the life span of two weeks, adult zooids undergo degeneration accompanied by apoptotic cell death (Lauzon et al., 2000). As the explants were chosen from the middle generation in this study, the expected remaining life span of explants was a maximum of 4-7 days. In fact, some explants dissociated into single cells in a few days; however, others remained intact for approximately a month. These observations suggest that programmed cell death (Lauzon et al., 1992, 2000) may not occur in vitro.

\section{Characterization of in vitro proliferative cells}

In this study, we established four proliferative cell lines from Botryllus explants. Partial nucleotide sequences for PCNA and mtIrRNA obtained from cultured cells were consistent with those obtained from colonies of $B$. primigenus. For reference, we compared Botryllus PCNA with that of related species of Polyandrocarpa and Styela, and found $75 \%$ similarity among them. These results indicate that all four cell lines are of Botryllus origin. The cell line Bp0306E10D1 comprised adherent cells that could form aggregates of various sizes. Initially, these were believed to be epithelial cells, as we had previously established a similar type of epithelial cell line from $P$. misakiensis (Kawamura and Fujiwara, 1995). However, the monoclonal antibody raised against the cultured cells did not recognize any epithelial tissues, but did stain free mesenchymal cells in the hemocoel in vivo. These mesenchymal cells, especially abundant in the vascular ampullae, were 8-10 $\mu \mathrm{m}$ in diameter and had many granules in the cytoplasm, features that are similar to those of granulocytes (Hirose et al., 2003).

Unlike the larger cells in the culture, the aggregated cells did not stain with the anti-28kDa antibody. This may indicate that the aggregated cells are indeed epithelial cells differentiating in vitro from round and somewhat amorphous cells. In budding tunicates, undifferentiated blood cells, i.e., hemoblasts, are known to adhere to form the epithelial tissues (Kawamura et al., 1991; Kawamura and Sugino, 1999). Hemoblasts that aggregate under the vascular epidermis form vascular buds (Oka and Watanabe, 1957b, 1959; Sabbadin et al., 1975), while those that aggregate in the gonadal space form a loose cell mass (i.e., germline precursor cells; Mukai and Watanabe, 1976; Sunanaga et al., unpublished data). If we can prepare antibodies that recognize the aggregating cells, we can further our understanding of hemoblast adhesion.

\section{Establishment of G418-resistant subclonal cells}

In this study, the cultured cells of Botryllus could be rescued from the lethal effect of the antibiotic G418 when a retrotransposon loaded with the neomycin resistance gene was introduced into them by means of electroporation. The 
retrotransposon was approximately $6.5 \mathrm{~kb}$ long. It has been isolated from the colonies of $P$. misakiensis (Kawamura et al., unpublished data), indicating that it works effectively across species. This is not unexpected, because recently it was discovered that the Drosophila transposable element Minos could be integrated efficiently into the genome of germ cells in $C$. intestinalis (Sasakura et al., 2003). Minos is transmitted stably to subsequent generations (Matsuoka et al., 2004), thereby enabling insertional mutagenesis (Awazu et al., 2004). Although we do not have any evidence for the integration of the retrotransposon into the genome of Botryllus culture cells, the transgenic cells continued to divide for at least 10 months. In the natural host $P$. misakiensis, the retrotransposon is expressed during both sexual and asexual reproduction (Kawamura et al., unpublished data). Therefore, Botryllus cell lines and retrotransposons may be useful as new tools for investigating gene function.

\section{ACKNOWLEDGMENTS}

We thank Dr. Shigeki Fujiwara for valuable discussions about cell culture. Thanks are also due to the staff of the Usa Marine Biological Institute of Kochi University for providing us with the facilities to keep living animals. K.K. expresses his deep respect to a professor emeritus Dr. Hiroshi Watanabe, who conducted pioneering research on Botryllus primigenus.

\section{REFERENCES}

Awazu S, Sasaki A, Matsuoka T, Satoh N, Sasakura Y (2004) An enhancer trap in the ascidian Ciona intestinalis identifies enhancers of its Musashi orthologous gene. Dev Biol 275: 459472

Berrill NJ (1941) The development of the bud in Botryllus. Biol Bull 80: $169-184$

Burighel P (1970) Sviluppo e differenziamento del tubo digerente nel blastozooide dell'ascidia coloniale Botryllus schlosseri (Pallas). Boll Zool 37: 177-192

Burighel P, Milanesi C (1977) Fine structure of the intestinal epithelium of the colonial ascidian Botryllus schlosseri. Cell Tissue Res 182: 357-369

Burighel P, Schiavinato A (1984) Degenerative regression of the digestive tract in the colonial ascidian Botryllus schlosseri (Pallas). Cell Tissue Res 235: 309-318

Burighel P, Lane NJ, Zaniolo G, Manni L (1998) Neurogenic role of the neural gland in the development of the ascidian, Botryllus schlosseri (Tunicata, Urochordata). J Comp Neur 394: 230-241

Casagrande L, Martinucci GB, Burighel P (1993) Origin and differentiation of branchial stigmata in the compound ascidian Botryllus schlosseri (Tunicata). Anim Biol 2: 111-121

Cima F, Basso G, Ballarin L (2003) Apoptosis and phosphatidylserine-mediated recognition during the take-over phase of the colonial life-cycle in the ascidian Botryllus schlosseri. Cell Tissue Res 312: 369-376

Ermak TH (1977) The hematogenic tissue of tunicates. In "The Phylogeny of Thymus and Bone Marrow-Bursa Cells" Ed by RK Wright, EL Cooper, Elsevier, Amsterdam, pp 45-56

Ermak TH (1981) A comparison of cell proliferation patterns in the digestive tract of ascidians. J Exp Zool 217: 325-339

Hirose E, Shirae M, Saito Y (2003) Ultrastructures and classification of circulating hemocytes in 9 botryllid ascidians (chordata: ascidiacea). Zool Sci 20: 647-656

Izzard CS (1973) Development of polarity and bilateral asymmetry in the palleal bud of Botryllus schlosseri (Pallas). J Morphol 139: 1-26

Kawamura K, Fujiwara S (1995) Establishment of cell lines from multipotent epithelial sheet in the budding tunicate, Polyandro- carpa misakiensis. Cell Struct Func 20: 97-106

Kawamura K, Nakauchi M (1986a) Development of spatial organization in palleal buds of the compound ascidian, Symplegma reptans. Biol Bull 171: 520-537

Kawamura K, Nakauchi M (1986b) Mitosis and body patterning during morphallactic development of palleal buds in ascidians. Dev Biol 116: 39-50

Kawamura K, Sugino YM (1999) Cell adhesion in the process of asexual reproduction of tunicates. Micro Res Tech 44: 269-278

Kawamura K, Fujiwara S, Sugino YM (1991) Budding-specific lectin induced in epithelial cells is an extracellular matrix component for stem cell aggregation in tunicates. Development 113: 9951005

Kawamura K, Shibata T, Saget O, Peel D, Bryant PJ (1999) A new family of growth factors produced by the fat body and active on Drosophila imaginal disc cells. Development 126: 211-219

Koyama H (2002) The dorsal strand of Polyandrocarpa misakiensis (Protochordata: Ascidiacea): a light and electron microscopic study. Acta Zool 83: 231-243

Lauzon RJ, Ishizuka KJ, Weissman IL (1992) A cyclical, developmentally-regulated death phenomenon in a colonial urochordate. Dev Dyn 194: 71-83

Lauzon RJ, Rinkevich B, Patton CW, Weissman IL (2000) A morphological study of nonrandom senescence in a colonial urochordate. Biol Bull 198: 367-378

Lauzon RJ, Ishizuka KJ, Weissman IL (2002) Cyclical generation and degeneration of organs in a colonial urochordate involves crosstalk between old and new: a model for development and regeneration. Dev Biol 249: 333-348

Matsuoka T, Awazu S, Satoh N, Sasakura Y (2004) Minos transposon causes germline transgenesis of the ascidian Ciona savignyi. Develop Growth Differ 46: 249-255

Mukai H, Watanabe H (1974) On the occurrence of colony specificity in some compound ascidians. Biol Bull 147: 411-421

Mukai H, Watanabe H (1976) Studies on the formation of germ cells in a compound ascidian Botryllus primigenus Oka. J Morph 148: 337-362

Oka H, Watanabe H (1957a) Colony specificity in compound ascidians as tested by fusion experiments (a preliminary report). Proc Jpn Acad 33: 657-659

Oka H, Watanabe H (1957b) Vascular budding, a new type of budding in Botryllus. Biol Bull 112: 225-240

Oka H, Watanabe H (1959) Vascular budding in Botrylloides. Biol Bull 117: 340-346

Pediee CM, Smith VJ (1993) In vitro spontaneous cytotoxic activity against mammalian target cells by the hemocytes of the solitary ascidian, Ciona intestinalis. J Exp Zool 267: 616-623

Pediee CM, Riches AC, Smith VJ (1995) Proliferation of undifferentiated blood cells from the solitary ascidian, Ciona intestinalis in vitro. Dev Comp Immunol 19: 377-387

Raftos DA, Cooper EL (1991) Proliferation of lymphocyte-like cells from the solitary tunicate, Styela clava, in response to allogeneic stimuli. J Exp Zool 260: 391-400

Raftos DA, Cooper EL, Habicht GS, Beck G (1991) Invertebrate cytokines: tunicate cell proliferation stimulated by an interleukin 1-like molecule. Proc Natl Acad Sci USA 88: 9518-9522

Raftos DA, Stillman DL, Cooper EL (1990) In vitro culture of tissue from the tunicate Styela clava. In Vitro Cell Dev Biol 26A: 962970

Rinkevich B, Rabinowitz C (1993) In vitro culture of blood cells from the colonial protochordate Botryllus schlosseri. In Vitro Cell Dev Biol 29A: 79-85

Rinkevich B, Lauzon RJ, Brown BW, Weissman IL (1992) Evidence for a programmed life span in a colonial protochordate. Proc Natl Acad Sci USA 89: 3546-3550

Sabbadin A (1962) Le basi genetiche della capacita di fusione fra colonies in Botryllus schlosseri (Ascidiacea). Rend Accad Naz 
Lincei Ser 8 32: 1031-1035

Sabbadin A, Zaniolo G (1979) Sexual differentiation and germ cell transfer in the colonial ascidian Botryllus schlosseri. J Exp Zool 207: 289-304

Sabbadin A, Zanbiolo G, Majone F (1975) Determination of polarity and bilateral asymmetry in palleal and vascular buds of the ascidian Botryllus schlosseri. Develop Biol 46: 79-87

Saiki RK, Gelfand DH, Stoffel S, Scharf SJ, Higuchi GT, Horn GT, Mullis KB, Erlich HA (1988) Primer-directed enzymatic amplification of DNA with a thermostable DNA polymerase. Science 239: 487-491

Saito Y, Hirose E, Watanabe $\mathrm{H}$ (1994) Allorecognition in compound ascidians. Int J Dev Biol 38: 237-247

Sasakura Y, Awazu S, Chiba S, Satoh N (2003) Germ-line transgenesis of the Tc1/mariner superfamily transposon Minos in Ciona intestinalis. Proc Natl Acad Sci USA 100: 7726-7730

Scofield VL, Nagashima LS (1983) Morphology and genetics of rejection reactions between oozooids from the tunicate Botryllus schlosseri. Biol Bull 165: 733-744
Scofield VL, Schlumpberger JM, West LA, Weissman IL (1982) Protochordate allorecognition is controlled by a MHC-like gene system. Nature 295: 499-502

Stoner DS, Weissman IL (1996) Somatic and germ cell parasitism in a colonial ascidian: possible role for a highly polymorphic allorecognition system. Proc Natl Acad Sci USA 93: 1525415259

Warr GW, Decker JM, Mandel TE, DeLuca D, Hudson R, Marchalonis JJ (1977) Lymphocyte-like cells of the tunicate, Pyura stolonifera: binding of lectins, morphological and functional studies. AJEBAK 55: 151-164

Watanabe $H$ (1953) Studies on the regulation in fused colonies in Botryllus primigenus (Ascidiae Compositae). Sci Rep Tokyo Bunrika Daigaku sec B 7:183-198

(Received October 28, 2005 / Accepted December 7, 2005) 